\title{
PENINGKATAN HASIL BELAJAR IPS MELALUI BAHAN AJAR DIALOGIS KOMIK SEPEKAN BERBANTUAN POWERPOINT DI KELAS 5B SDN SAMPANGAN 01
}

\author{
Dian Marta Wijayanti
}

\author{
SDN Sampangan 01 \\ girlsmarta@gmail.com
}

\begin{abstract}
Abstrak
Ketuntasan pembelajaran IPS di kelas 5B SDN Sampangan 01 hanya 36\%. Pembelajaran sebelumnya masih berlangsung kurang inovatif. Guru hanya menggunakan buku paket tanpa dibantu bahan ajar lain yang lebih menarik. Maka dari itu peneliti memperbaiki kegiatan pembelajaran dengan menggunakan bahan ajar dialogis KOMIK SEPEKAN. Metode yang digunakan dalam penelitian ini adalah Penelitian Tindakan Kelas dengan 3 siklus. Subyek penelitian adalah siswa kelas 5B SDN Sampangan 01 tahun 2016. Hasil penelitian memperlihatkan adanya peningkatan aktivitas siswa. Pembelajaran berjalan lebih bermakna karena siswa dapat memahami kronologi peristiwa sejarah pasca kemerdekaan melalui bahan ajar yang memiliki warna menarik. Ketuntasan klasikal meningkat dari 36\% menjadi $80 \%$.
\end{abstract}

Kata kunci: IPS, komik, powerpoint

\section{Abstact}

The completeness of IPS learning in 5B grader of Sampangan 01 elementary school onl $36 \%$, because the previous learning is conducted less innovative. The teacher only use school book without another interesting complement teaching material. Because of that case, the writer construct learning activity by using teaching material dialogis KOMIK SEPEKAN. This study using action research with 3 cycles. The subject is $5 B$ graders of Sampangan 01 elementary school in 20016. The result show there is increasing on student activity. Learning activity runs meaningfull because students easy to understand the chronology of Indonesia history after independence by teaching material which has interesting atmosphere. Clasical completeness is increase from $36 \%$ to $80 \%$.

Keywords: IPS, comic, powerpoint 


\section{A. PENDAHULUAN}

Berdasarkan Standar Kompetensi dan Kompetensi Dasar Tingkat SD/MI dalam Peraturan Menteri Pendidikan Nasional Nomor 22 Tahun 2006 tentang Standar Isi untuk Satuan Pendidikan Dasar dan Menengah, tujuan mata pelajaran IPS adalah untuk mengarahkan peserta didik menjadi warga negara Indonesia yang demokratis, dan bertanggung jawab, serta warga dunia yang cinta damai. Salah satu ciri mata pelajaran IPS adalah menelaah masalah-masalah yang terjadi di masyarakat dengan perkembangan ilmu pengetahuan, teknologi, dan komunikasi.Kajian IPS lebih ditekankan pada masalah-masalah sosial budaya yang terdapat di masyarakat.Tidak hanya pada masa sekarang, namun juga pada masa lampau dalam rangka mengantisipasi perubahan sosial budaya beserta dampaknya terhadap kelangsungan hidup manusia.

Pelaksanaan pembelajaran IPS di SDN Sampangan 01 khususnya pada kelas $\mathrm{V}$ masih banyak menemui kendala baik dalam pembelajaran maupun penilaian. Hal ini tercermin dari hasil belajar yang diperoleh peserta didik masih kurang optimal. IPS dianggap sebagai mata pelajaran yang sukar. Beberapa yang menjadi masalah adalah anak tidak gemar memahami materi melalui bacaan. Setiap kali pembelajaran IPS dilaksanakan, masih banyak peserta didik malas membaca buku ajar. Bahkan ada peserta didik yang hanya melihat buku tanpa membaca sama sekali.

Keadaan tersebut tentu membuat peserta didik pasif dalam pembelajaran. Hanya beberapa siswa yang masih antusias dalam mengikuti pembelajaran IPS. Meskipun beberapa kali pendidik telah mencoba pembelajaran kelompok, tapi masih saja pembelajaran dinilai kurang 
efektif. Hanya beberapa siswa yang terlihat aktif dalam menyelesaikan masalah yang diberikan.

Pengamatan awal terhadap hasil ulangan harian peserta didik kelas VB SDN Sampangan 01 dari 25 siswa hanya 9 peserta didik yang mendapat nilai di atas 65 dan 16 peserta didik belum mencapai Kriteria Ketuntasan Minimal (KKM) yang ditetapkan yaitu 65. Data di atas diketahui ketuntasan klasikal $36 \%$ padahal standar ketuntasan adalah $75 \%$.

Salah satu usaha pendidik agar pembelajaran berjalan lebih efektif dan efisien adalah mengembangkan bahan ajar yang sesuai dengan materi dan perkembangan peserta didik. Dalam hal ini, pendidik memilih bahan ajar dialogis komik edukasi berbantuan media powerpoint sebagai alternatif solusi dalam upaya pencapaian tujuan pembelajaran. Pendidik berusaha meningkatkan kemampuan peserta didik melalui penelitian yg berjudul“Peningkatan Hasil Belajar IPS Melalui Bahan Ajar Dialogis Komik SEPEKAN Berbantuan Power Point di Kelas 5 SDN Sampangan 01"

\section{B. LANDASAN TEORI}

\section{a. Belajar dan Pembelajaran}

Menurut Anni belajar merupakan proses penting bagi perubahan perilaku manusia dan mencakup segala sesuatu yang dipikirkan dan dikerjakan. Belajar memegang peranan penting di dalam perkembangan,kebiasaan, sikap, keyakinan, tujuan, kepribadian, dan bahkan persepsi manusia. ${ }^{1}$ Namun belajar juga diartikan sebagai suatu proses perubahan tingkah laku individu melalui interaksi dengan lingkungan. Menurut Hamalik aspek tingkah laku tersebut

${ }^{1}$ C.T Anne, Psikologi Belajar, Semarang: UPT MKK UNNES, 2006, hlm.2 
adalahpengetahuan, pengertian, kebiasaan, keterampilan, apresiasi, emosional, hubungan sosial, jasmani, etis dan budi pekerti dan sikap. ${ }^{2}$

Berbeda dengan pengertian belajar. Pembelajaran merupakan interaksi dua arah dari seorang guru dan peserta didik, di mana antara keduanya terjadi komunikasi (transfer) yang intens dan terarah menuju pada suatu target yang ditetapkan sebelumnya. Definisi di atas dapat diketahui bahwa belajar dan pembelajaran memiliki hubungan yang sangat erat. Proses belajar tidak akan berjalan dengan baik jika tidak ada pembelajaran yang terarah dan saling menguatkan.

\section{b. Pembelajaran IPS di Sekolah Dasar}

Menurut Hidayati, dkk bidang studi IPS merupakan gabungan ilmuilmu sosial yang terintegrasi atau terpadu ${ }^{3}$. Karakteristik pembelajaran IPS di Sekolah Dasar dapat dilihat dari materi dan strategi penyampaiannya.

\section{c. Bahan Ajar}

Bahan ajar merupakan bagian dari sumber belajar. Bahan ajar adalah segala bentuk bahan yang digunakan untuk membantu guru/instruktor dalam melaksanakan kegiatan belajar mengajar. Bahan yang dimaksud bisa berupa bahan tertulis maupun bahan tidak tertulis.Bahan ajar atau teaching-material, terdiri atas dua kata yaitu teaching atau mengajar dan material atau bahan.

Bahan ajar merupakan seperangkat materi/substansi pembelajaran (teaching material) yang disusun secara sistematis, menampilkan sosok utuh dari kompetensi yang akan dikuasai siswa dalam kegiatan pembelajaran. Bahan ajar memungkinkan siswa dapat mempelajari suatu hlm.22.

20emar Hamalik,Proses Belajar Mengajar,Jakarta: Bumi Aksara, 2004,

${ }^{3}$ Hidayati, Mujinem, dan Anwar Senen, Pengembangan Pendidikan IPS SD, Jakarta: Direktorat Jenderal Pendidikan Tinggi Departemen Pendidikan Nasional, 2004, hlm. 26 
kompetensi atau kompetensi dasar secara runtut dan sistematis sehingga secara akumulatif mampu menguasai semua kompetensi secara utuh dan terpadu.

\section{d. Komik}

McCloud dalam MS Gumelar memaparkan definisi "komik adalah gambar yang berjajar dalam urutan yang disengaja dimaksudkan untuk menyampaikan informasi atau menghasilkan respon estetik dari pembaca". 4 Komik dalam etimologi bahasa Indonesia berasal dari kata "comic" yang kurang lebih secara semantik berarti lucu. Berdasarkan pengertian tersebut dapat dipahami secara umum bahwa komik adalah sesuatu yang identik dengan suatu hal yang lucu. Lucu dalam hal ini mencakup segi gambar tokoh yang ditampilkan dan juga konten yang ada pada komik tersebut.

Nana Sudjana dan Ahmad Rivai memberikan definisi yang senada bahwa komik adalah suatu bentuk kartun yang mengungkapkan karakter dan memerankan suatu cerita dalam urutan yang erat dihubungkan dengan gambar untuk memberikan hiburan kepada para pembacanya ${ }^{5}$. Berdasarkan definisi yang berasal dari para tokoh tersebut tidak heran jika predikat menghibur dan menyenangkan telah melekat pada komik semenjak awal kemunculannya pada tahun 1980-an.

\section{e. Microsoft Power Point}

Microsoft Power Point adalah program komputer yang dikhususkan untuk presentasi. Microsoft Power Point ini merupakan pengembangan dari microsoft lainnya. Aplikasi Microsoft Power Point ini pertama kali dikembangkan oleh Bob Gaskin dan Dennis Austin sebagai presentator 2011, hlm.6

${ }^{4}$ MS. Gumelar, 2D Animation Hybrid Technique Book A, Jakarta: PT.Indeks,

${ }^{5}$ Nana Sudjana dan Ahmad Rivai,Media Pengajaran, Bandung: Sinar Baru Algesindo, 2005, hlm.25 
untuk perusahaan bernama Forethought, Inc yang kemudian mereka ubah namanya menjadi Power Point.

Penggunaan fitur-fitur media power point tentunya akan memberikan tambahan nilai estetika. Dimana dengan menggunakan fiturfitur ini diharapkan presentasi akan menjadi lebih hidup. Menurut Erlina dalam KBM siswa tertarik dahulu mengenai tampilan power point sehingga memungkinkan untuk memperhatikan apa yang diajar oleh guru. ${ }^{6}$ Powerpoint membantu guru dalam menyajikan dan memperjelas materi pelajaran dengan kegiatan yang variatif dan suasana yang tidak membosankan. Siswa akan lebih termotivasi untuk belajar dan lebih mudah memahami materi yang diajarkan oleh guru.

Secara umum kelebihan penggunaan media power point dalam KBM menurut Etin Solihatin adalah sebagai berikut: 1) menyampaikan materi pelajaran dapat diseragamkan; 2) proses pembelajaran menjadi lebih jelas dan menarik; 3) proses pembelajaran menjadi lebih interaktif; 4) efisiensi dalam waktu dan tenaga; 5) meningkatkan kualitas hasil belajar siswa; 6) Media dapat menumbuhkan sikap positif siswa terhadap materi yang disampaikan guru dan proses belajar. ${ }^{7}$

Ketepatan penggunaan media power point yaitu dapat membantu pencapaian keberhasilan belajar siswa. Penggunaan media power point adalah salah satu alat bantu yang digunakan pada saat proses pembelajaran berlangsung. Penggunaan media power point akan memudahkan siswa dalam memahami materi yang disampaikan. Penggunaan media power point tentunya juga akan melatih daya ingat siswa karena terdapat penggunaan warna dalam slide power point.

\footnotetext{
${ }^{6}$ Erlina,Supermedia, Jakarta: Erlangga, 2009, hlm. 2

${ }^{7}$ Etin Solihatin,Strategi Pembelajaran PPKn, Jakarta: Bumi Aksara,2012, hlm. 186-188
} 
Pembelajaran yang menarik seperti ini akan menjadikan pembelajaran yang sangat menyenangkan. Dalam kegiatan belajar mengajar power point memberikan posisi yang sangat strategis dimana power point merupakan objek sehingga dengan kecanggihan power point dan fitur-fitur yang tersedia dalam power point akan menarik perhatian siswa atau dapat dikatakan dapat mengendalikan perhatian siswa.

\section{METODOLOGI PENELITIAN}

Rancangan yang ditetapkan dalam penelitian ini adalah penelitian tindakan kelas (Classroom action research). Penelitian Tindakan Kelas (PTK) adalah penelitian yang dilakukan oleh guru di kelasnya sendiri melalui refleksi diri dengan tujuan untuk memperbaiki kinerjanya sehingga hasil belajar siswa meningkat. ${ }^{8}$ Peneliti menggunakan dua siklus dengan 1 siklus 3 pertemuan agar mencapai tingkat keberhasilan yang telah ditentukan. Adapun langkah-langkah PTK setiap siklus terdiri dari perencanaan, tindakan, observasi dan refleksi.

Penelitian ini dilaksanakan pada siswa kelas VB SDN Sampangan 01 dengan jumlah 25 siswa yang terdiri dari 15 siswa laki-laki dan 10 siswa perempuan. Jenis data dalam penelitian ini adalah kuantitatif dan kualitatif. Kuantitatif adalah data yang berbentuk bilangan, harganya berubah-ubah atau bersifat variabel. ${ }^{9}$ Data ini diwujudkan dengan tes evaluasi.

Data kualititatif adalah data yang berbentuk kategori atau atribut. Data kualitatif berupa informasi berbentuk kalimat yang memberikan gambaran tentang pemahaman siswa terhadap suatu mata pelajaran (kognitif), pandangan atau sikap siswa terhadap metode belajar yang baru hlm. 3

8 Zainal Aqib, Penelitian Tindakan Kelas, Bandung: Yrama Widya, 2010,

9 Nana Sudjana,Penilaian Hasil Proses Belajar Mengajar, Bandung: PT. Remaja Rosdikarya, 2005. 
(afektif), aktivitas siswa mengikuti pelajaran, perhatian, antusias dalam belajar, kepercayaan diri, motivasi belajar, dan sejenisnya. Data ini diperoleh dari hasil observasi dengan menggunakan lembar pengamatan aktivitas siswa, keterampilan guru, catatan lapangan, dan pedoman wawancara dalam pembelajaran IPS.

Teknik pengumpulan data yang dilakukan pada penelitian ini adalah dengan menggunakan teknik tes dan teknik nontes. Teknik tes yang digunakan adalah tes tertulis untuk menguji hasil belajar siswa. Sedangkan teknik nontesnya adalah observasi, wawancara, dan catatan lapangan selama pembelajaran berlangsung.

Data kuatitatif berupa hasil belajar untuk mengukur hasil belajar siswa yang dianalisis untuk menentukan mean. Data kuantitatif akan disajikan dalam bentuk persentase.

$\mathrm{N}=\frac{B}{S t} \times 100$

Keterangan:

$\mathrm{B}=$ Banyaknya butir yang dijawab benar (dalam bentuk pilihan ganda) atau jumlah skor jawaban benar pada tiap butir/ item soal pada tes bentuk uraian).

St $=$ Skor teoritis (banyaknya butir soal pada pilihan ganda, jumlah skor seluruhnya).

$\mathrm{N}=$ nilai

Untuk menghitung hasil ketuntasan klasikal digunakan rumus

Menggunakan rumus sebagai berikut:

$\%$ ketuntasan belajar $=\frac{j \text { jumlah siswa tuntas }}{\text { jumlah siswa tidak tuntas }} \times 100 \%$ 
Tabel 1.1. Kriteria Ketuntasan belajar

\begin{tabular}{|c|c|l|}
\hline \multicolumn{2}{|c|}{ Kriteria ketuntasan } & \multirow{2}{*}{ Kualifikasi } \\
\cline { 1 - 2 } Klasikal & Individual & \\
\hline$\geq 80 \%$ & $\geq 65$ & Tuntas \\
\hline$<80 \%$ & $<65$ & Tidak Tuntas \\
\hline
\end{tabular}

Sumber: KKM SDN Sampangan 01 Semarang Tahun Pelajaran 2015/2016

Data kualitatif berupa data observasi, catatan lapangan dan wawancara. Adapun langkah penganalisisan data kualitatif adalah dengan menganalisis lembar observasi yang telah diisi ketika pembelajaran dan mengklasifikasikannya dengan teman peneliti yang membantu dalam penelitian. Data catatan lapangan dianalisis dengan cara melihat kembali catatan-catatan kecil saat pembelajaran berlangsung. Sedangkan wawancara merupakan penilaian yang dilakukan mencari informasi pada narasumber. Data kualitatif ini dipaparkan dalam kalimat yang dipisahkan menurut kategori untuk memperoleh kesimpulan.

Data kualitatif diperoleh dari lembar pengamatan terhadap aktivitas siswa dan keterampilan guru mengelola kelas selama proses pembelajaran. Kriteria penilaian dalam lembar pengamatan tersusun dalam bentuk deskriptor berdiri sendiri dengan skor terendah 1 dan skor tertinggi 4 .

\section{HASIL DAN PEMBAHASAN}

Hasil penelitian yang disajikan peneliti merupakan hasil tes dan nontes yang berasal dari prasiklus, hasil siklus I dan hasil siklus II. Hasil prasiklus merupakan hasil pembelajaran IPS siswa sebelum menggunakan bahan ajar dialogis Komik SEPEKAN berbantuan powerpoint. Sedangkan 
hasil siklus I dan siklus II merupakan hasil pembelajaran IPS siswa sebelum mengan aj Komik SEPEKAN berbantuan powerpoint.

\section{a. Paparan Data Prasiklus}

Berdasarkan temuan dari kegiatan prasiklus diperoleh permasalahan bahwa pembelajaran IPS di kelas 5B SDN Sampangan 01 pada materi perjuangan setelah kemerdekaan terdapat 16 dari 25 siswa (64\%) tidak tuntas KKM. Kondisi tersebut memerlukan tindakan perbaikan dalam bentuk classroomaction research atau penelitian tindakan kelas.

Identifikasi IPS di kelas VB SDN Sampangan 01, yaitu: (1) Siswa sering tidak memperhatikan penjelasan dari guru; (2) siswa terlihat bingung ketika diminta menyusun karangan dalam bentuk narasi; (3) guru kurang optimal dalam menggunakan model pembelajaran inovatif; (4) guru belum menggunakan media pembelajaran yang menarik perhatian siswa; (5) KBM tidak menarik perhatian siswa; (6) referensi untuk pembelajaran IPS kurang lengkap. Hal tersebut menyebabkan hasil belajar siswa masih belum memenuhi kriteria ketuntasan klasikal sebesar 80\%. Data hasil belajar siswa dapat dinyatakan dalam tabel berikut ini:

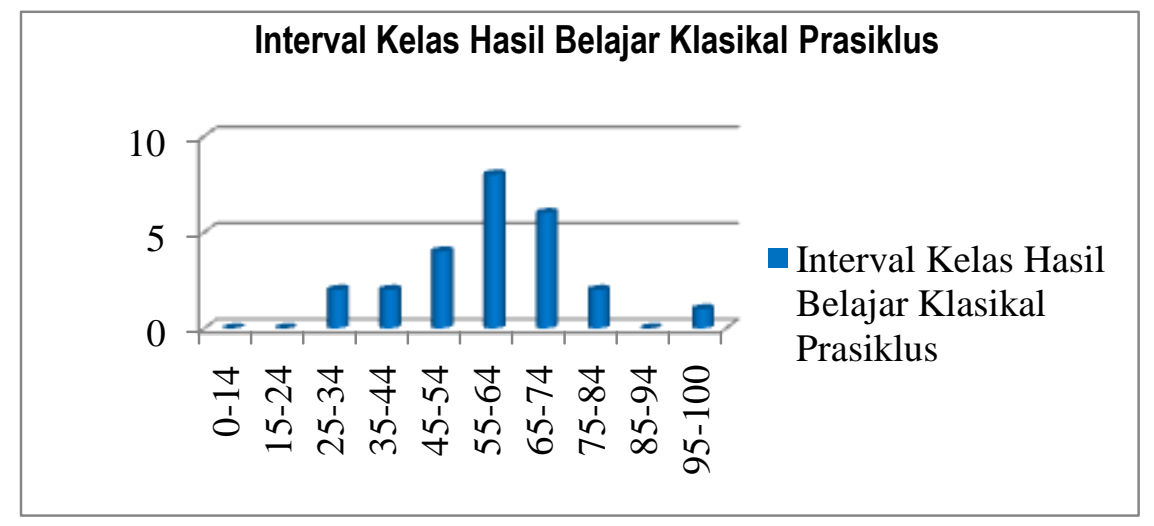

Diagram 1.1 Analisis Data Hasil Belajar Pra Siklus 


\section{b. Aktivitas Siswa}

1. Mempersiapkan diri menerima pembelajaran

Berdasarkan hasil observasi aktivitas siswa indikator mempersiapkan diri menerima pelajaran terjadi peningkatan dari siklus I ke siklus II. Deskriptor yang paling sering muncul adalah siswa sudah di dalam kelas, menempati tempat duduk, tidak bermain sendiri tapi belum mengeluarkan perlengkapan belajar. Peningkatan rata-rata skor di atas memperlihatkan bahwa kesiapan siswa dalam mempersiapkan diri menerima pelajaran sudah lebih baik.

Indikator mempersiapkan diri menerima pelajaran termasuk emotional activities. Hal tersebut sesuai pendapat Diedrich emotional activities mencakup minat, merasa bosan, gembira, bersemangat, bergairah dan gugup. ${ }^{10}$ Peningkatan aktivitas siswa di atas terjadi karena kesiapan iklim lingkungan belajar merupakan bagian dari faktor eksternal sehingga mempengaruhi perubahan tingkah laku pada anak. Beberapa kondisi ekternal yang ada di lingkungan peserta didik adalah variasi dan tingkat kesulitan belajar (stimulus) yang dipelajari atau direspon, tempat belajar, iklim, suasana lingkungan, dan budaya belajar masyarakat. Jadi perubahan tingkah laku yang terjadi merupakan hasil atau akibat dari upaya-upaya atau latihan yang dilakukan secara sadar dan mempunyai tujuan.

2. Memperhatikan penjelasan guru melalui media

Berdasarkan hasil observasi indikator aktivitas siswa memperhatikan media dalam mengikuti pembelajaran pada siklus I meningkat di siklus II. Deskriptor yang paling sering muncul adalah siswa memperhatikan Komik SEPEKAN. Siswa juga mencermati penggunaan katakata yang terdapat dalam komik. Namun siswa tidak menanyakan hal-hal

10 Sardiman,AM,Interaksi dan Motivasi Belajar, Jakarta: PT. Rajagrafindo Persada, 2011, hlm. 104 
yang kurang jelas jika guru tidak menunjuk nama siswa tersebut. Perubahan skor yang terjadi dipengaruhi oleh kesiapan siswa dalam menggunakan media catatan harian. Pada siklus I diketahui bahwa beberapa siswa belum paham isi cerita. Beberapa siswa yang lain menulis cerita dengan kalimatnya sendiri. Setelah mendapatkan bimbingan dari guru, pada siklus II kemampuan siswa dalam memahami Komik dan media powerpoint semakin bertambah.

Media powerpoint dan Komik termasuk dalam visual activities. Bagian dari visual activities meliputi antara lain membaca, melihat gambar, mengamati eksperimen, demonstrasi, pameran, dan mengamati orang lain bekerja atau bermain. Indikator tersebut perlu untuk dikembangkan karena kemampuan siswa dalam memperhatikan media akan mempengaruhi hasil pembelajaran siswa pada pertemuan tersebut. Hal ini sesuai pendapat dari Gagne mengartikan media sebagai jenis komponen dalam lingkungan siswa yang dapat merangsang mereka untuk belajar.11 Oleh karena itu, suatu media dapat disebut sebagai media pembelajaran jika membawa pesan untuk suatu tujuan pembelajaran

3. Menjawab serangkaian pertanyaan

Berdasarkan hasil observasi aktivitas siswa indikator menjawab serangkaian pertanyaan yang diberikan oleh guru dalam mengikuti pembelajaran pada siklus I dan siklus II deskriptor yang paling sering muncul adalah siswa dapat menjawab pertanyaan dengan benar serta bersedia memperbaiki jawaban teman.

Aktivitas siswa dalam indikator ini merupakan oral activities yang meliputi menyatakan, merumuskan, bertanya, memberi saran,

11Departemen Pendidikan Nasional, Kurikulum Berbasis Kompetensi: Ketentuan Umum Pendidikan Prasekolah, Dasar, dan Menengah Umum, Jakarta: Depdiknas, 2003. 
mengeluarkan pendapat, mengadakan wawancara, diskusi, interupsi. Sedangkan mental activities meliputi menanggapi, mengingat, memecahkan soal, menganalisis, melihat hubungan, dan mengambil keputusan. Peningkatan aktivitas disebabkan karena dalam pembelajaran siswa dibimbing untuk berani bertanya dan menjawab pertanyaan. Pada siklus I guru menunjuk siswa sebagai perwakilan kelompok untuk menjawab pertanyaan. Padahal ada beberapa siswa yang ingin sekali bisa menjawab pertanyaan tersebut sehingga terjadi kerusuhan dalam kelas. Selain itu pertanyaan pada siklus I lebih membahas unsur intrinsik cerita sehingga siswa cenderung bosan.

Pertanyaan pada siklus II lebih ditekankan pada peran tokoh perjuangan yang dibuat oleh teman sekelompok. Guru menunjuk 2 siswa dalam satu kelompok sehingga siswa mau tidak mau akan siap untuk menerima pertanyaan. Siswa juga menjadi lebih siap memahami isi cerita milik teman sekelompok ketika diberi waktu oleh guru untuk berbagi cerita. Siklus II telah menunjukkan adanya perubahan pada sikap siswa. Sesuai dengan pendapat Sudjana perubahan sebagai hasil proses belajar dapat ditunjukkan dalam berbagai bentuk seperti berubah pengetahuannya, pemahamannya, sikap dan tingkah lakunya, keterampilannya, kecakapan dan kemampuannya, daya reaksinya, daya penerimaannya dan lain-lain aspek yang ada pada individu. 12Perubahan yang telah terjadi dalam indikator menjawab serangkaian pertanyaan lebih pada perubahan pengetahuan, ketrampilan dan daya reaksi respon pada pertanyaan. Apalagi jika dari setiap jawaban yang muncul guru selalu memberikan ulasan. Keterampilan siswa menjawab pertanyaan terlihat dari kecepatan siswa

\footnotetext{
${ }^{12}$ Nana Sudjana,Penilaian Hasil Proses Belajar Mengajar(Bandung: PT Remaja Rosdakarya, 2009) HIm. 28
} 
dalam menemukan jawaban. Menurut hasil catatan lapangan siswa sangat bersemangat menjawab cerita tentang kronologi cerita perjuangan.

4. Memberikan tanggapan tentang peran tokoh perjuangan

Berdasarkan hasil observasi aktivitas siswa indikator memberikan tanggapan terhadap jawaban teman. Deskriptor yang paling sering muncul adalah siswa kurang memperhatikan alasan mereka ketika memberikan tanggapan. Untuk dapat memberikan tanggapan, siswa menukarkan hasil pekerjaannya dengan teman yang lain. Siswa diberi waktu kurang lebih 5 menit untuk mencermati jawaban milik teman. Setelah waktu yang ditentukan selesai, siswa mulai menjawab pertanyaan yang diberikan guru dalam probing question. Guru tidak memberikan kunci jawaban yang benar tapi siswa yang tulisannya dikoreksi, diminta untuk memberikan tanggapan. Pada siklus I siswa yang tulisannya dikoreksi masih terlihat bingung sehingga tanggapan timbale balik untuk jawaban dilakukan oleh guru. Namun pada siklus II siswa sudah mulai paham dan dapat menanggapi jawaban maupun kritikan yang diberikan oleh teman tentang kesalahan yang dilakukan.

Keterampilan siswa yang termasuk dalam indikator ini adalah visual activities, oral activities, dan mental activities. Visual activities meliputi membaca, melihat gambar, mengamati eksperimen, demonstrasi, pameran, dan mengamati orang lain bekerja atau bermain. Oral activities meliputi mengemukakan suatu fakta atau prinsip, menghubungkan suatu kejadian, mengajukan, pertanyaan, memberi saran, mengemukakan pendapat, wawancara, diskusi, interupsi. Tanggapan yang diberikan siswa kepada teman sekelompok sangat berpengaruh terhadap kualitas karangan narasi yang telah ditulis. Menurut Tarigan tulisan yang baik mencerminkan kebanggaan penulis dalam naskah atau manuskrip: kesudian mempergunakan ejaan dan tanda baca secara saksama, memeriksa makna 
kata dan hubungan ketatabahasaan dalam kalimat-kalimat serta memperbaikinya sebelum menyajikannya kepada para pembaca. ${ }^{13}$

\section{c. Hasil Belajar Siswa}

Hasil belajar siswa mengalami peningaktaan dari siklus I ke siklus II. Hal ini merupakan pengaruh dari peningkatan aktivitas siswa dan keterampilan guru. Kehadiran bahan ajar yang relevan sangat berpengaruh terhadap motivasi dan pemahaman siswa dalam mengikuti pembelajaran. Peranan pokok dari buku komik dalam instruksional adalah kemampuannya dalam menciptakan minat peserta didik.

Peningkatan hasil belajar siswa dari siklus I ke siklus II diperlihatkan dalam tabel di bawah ini:

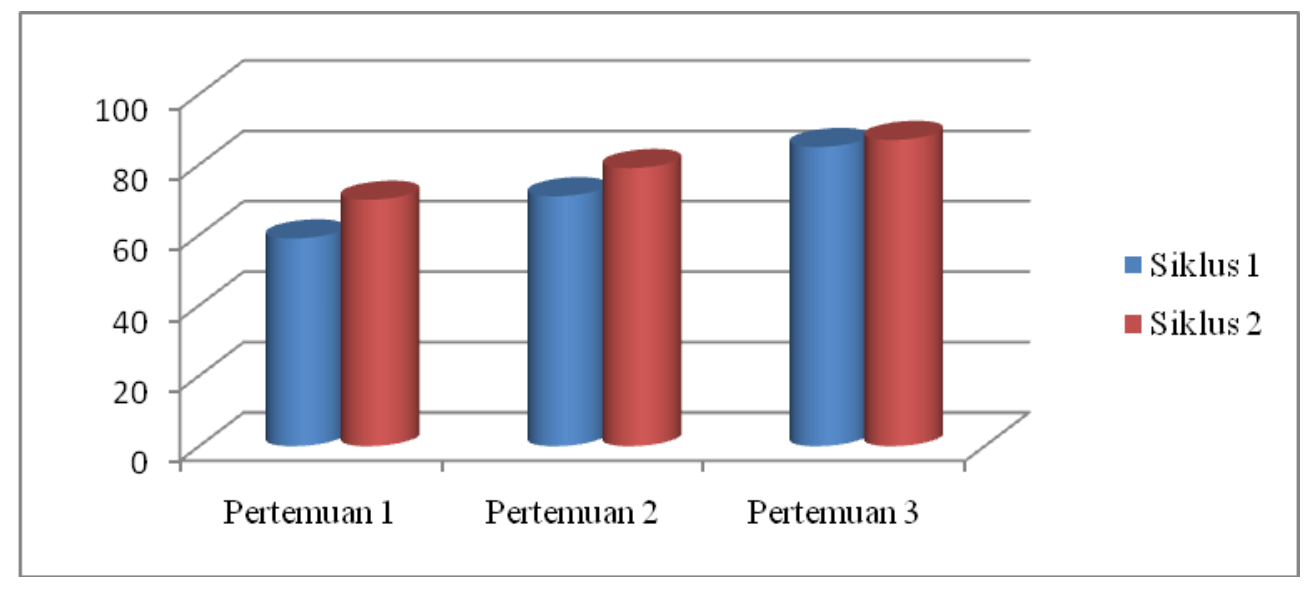

Diagram 1.2 Peningkatan Hasil Belajar IPS dari Siklus I ke Siklus II

\section{d. Implikasi Hasil Penelitian}

Hasil penelitian pembelajaran IPS melalui bahan ajar dialogis Komik Sepekan berbantuan Powerpoint terlihat terjadi peningkatan kualitas

13 Tarigan, Henry Guntur, Membaca Sebagai Suatu Keterampilan Berbahasa,(Bandung: Angkasa, 2008) Hlm. 6 
aktivitas siswa, keterampilan guru dan hasil belajar siswa. Hal ini dapat membuktikan bahwa bahan ajar dialogis Komik Sepekan dapat diterapkan dalam pembelajaran IPS di kelas 5. Setelah dilaksanakan penelitian ini, terdapat beberapa implikasi sebagai berikut:

a. Keberhasilan pembelajaran IPS dengan bahan ajar dialogis Komik Sepekan berbantuan powerpoint tidak terlepas dari pengaruh faktor guru dan siswa. Keterampilan guru dalam mengajar dan keaktifan siswa menjadi faktor keberhasilan pembelajaran. Hal ini akan memberikan kontribusi kepada guru untuk mengembangkan wawasan akan berbagai bahan ajar dan media pembelajaran yang inovatif.

b. Penelitian ini dilakukan sebagai upaya meningkatkan hasil belajar siswa dalam mata pelajaran IPS.

c. Penelitian ini menambah wawasan tentang penelitian tindakan kelas sehingga dapat memotivasi guru dan peneliti lain untuk melakukan penelitian sejenis sebagai upaya perbaikan kualitas pembelajaran.

d. Hasil penelitian ini digunakan sebagai acuan bagi sekolah untuk meningkatkan kualitas pembelajaran dengan menggunakan bahan ajar dialogis Komik Sepekan berbantuan powerpoint.

\section{E. SIMPULAN}

Berdasarkan hasil penelitian yang dilakukan peneliti dapat disimpulkan bahwa penggunaan Komik SEPEKAN dalam pembelajaran Ilmu Pengetahuan Sosial dapat meningkatkan kualitas aktivitas siswa. Aktivitas siswa yang dapat dilihat dari mempersiapkan diri menerima pembelajaran, memperhatikan pembelajaran guru melalui media, menjawab serangkaian pertanyaan, dan memberikan tanggapan tentang peran tokoh perjuangan 
Hasil belajar siswa dalam pembelajaran Ilmu Pengetahuan Sosial melalui bahan ajar dialogis Komik Sepekan berbantuan powerpoint mengalami peningkatan dan mencapai ketuntasan klasikal sebesar 80\%. 


\section{DAFTAR PUSTAKA}

Anne, CT, Psikologi Belajar, Semarang: UPT MKK UNNES, 2006.

Aqib, Zainal, Penelitian Tindakan Kelas. Bandung: Yrama Widya, 2010.

Departemen Pendidikan Nasional. Kurikulum Berbasis Kompetensi: Ketentuan Umum Pendidikan Prasekolah, Dasar, dan Menengah Umum. Jakarta: Depdiknas, 2003.

Erlina., Supermedia. Jakarta: Erlangga, 2009.

Gumelar,MS, 2D Animation Hybrid Technique Book A, Jakarta: PT.Indeks, 2011.

Hamalik, Oemar, Proses Belajar Mengajar, Jakarta: Bumi Aksara, 2004.

Hidayati, Mujinem, dan Anwar Senen, Pengembangan Pendidikan IPS SD. Jakarta: Direktorat Jenderal Pendidikan Tinggi Departemen Pendidikan Nasional, 2008.

Sardiman,AM, Interaksi dan Motivasi Belajar, Jakarta: PT.Rajagrafindo Persada, 2011.

Solihatin, Etin, Strategi Pembelajaran PPKn. Jakarta: Bumi Aksara, 2012.

Sudjana, Nana dan Ahmad Rivai, Media Pengajaran. Bandung: Sinar Baru Algesindo, 2005.

Penilaian Hasil Proses Belajar Mengajar, Bandung: PT. Remaja Rosdikarya, 2005.

Tarigan, Henry Guntur, Membaca Sebagai Suatu Keterampilan Berbahasa, Bandung: Angkasa, 2008.

113 MAGISTRA - Volume 8 Nomor 2 Desember 2017 